\title{
RESPONS TANAMAN RADISH (Raphanus sativus L.) VARIETAS LONG WHITE LCICLE YANG DIPUPUK KNO 3 BERBAGAI DOSIS TERHADAP APLIKASI MULSA
}

\author{
Bambang Wijonarko, Azlina Heryati Bakrie \& Kuswanta Futas Hidayat \\ Alumni Jurusan Budidaya Pertanian, Fakultas Pertanian Universitas Lampung \\ Jl. Soemantri Brojonegoro No. 1 Bandar Lampung 35145 \\ E-mail:djava45@yahoo.co.id
}

\begin{abstract}
ABSTRAK
Pada tanaman radish pupuk $\mathrm{KNO}_{3}$ berfungsi untuk membantu meningkatkan proses pembentukan umbi dan mulsa berfungsi untuk menghindari kehilangan air melalui penguapan dan menekan pertumbuhan gulma. Penelitian ini bertujuan untuk mengetahui (1) pengaruh pemberian beberapa taraf dosis pupuk $\mathrm{KNO}_{3}$ yang menghasilkan respons terbaik tanaman radish, (2) mengetahui respons tanaman radish akibat aplikasi mulsa, (3) mengetahui respons tanaman radish akibat pemupukan $\mathrm{KNO}_{3}$ berbagai dosis yang diaplikasikan pada lahan dengan mulsa dan tanpa mulsa. Penelitian ini dilaksanakan di Laboraturium Lapang Terpadu Fakultas Pertanian Universitas Lampung, Kota Bandar Lampung pada bulan Mei hingga Juni 2012. Rancangan lingkungan yang digunakan adalah Rancangan Kelompok Teracak Sempurna dengan tiga ulangan. Rancangan perlakuan disusun secara faktorial $(5 \times 2)$. Faktor pertama adalah dosis pupuk $\mathrm{KNO}_{3}(\mathrm{~K})$ yang terdiri dari 5 taraf, yaitu $0 \mathrm{~kg} \mathrm{ha}^{-1}\left(\mathrm{~K}_{0}\right) ; 75$ $\mathrm{kg} \mathrm{ha}^{-1}\left(\mathrm{~K}_{1}\right) ; 150 \mathrm{~kg} \mathrm{ha}^{-1}\left(\mathrm{~K}_{2}\right) ; 225 \mathrm{~kg} \mathrm{ha}^{-1}\left(\mathrm{~K}_{3}\right)$; dan $300 \mathrm{~kg} \mathrm{ha}^{-1}\left(\mathrm{~K}_{4}\right)$. Faktor kedua adalah aplikasi mulsa (M) yang terdiri dari dua taraf yaitu tanpa pemberian mulsa $\left(\mathrm{M}_{0}\right)$, dan mulsa plastik hitam perak $\left(\mathrm{M}_{1}\right)$. Hasil penelitian menunjukkan bahwa dosis pupuk $\mathrm{KNO}_{3}$ sampai dosis $300 \mathrm{~kg} \mathrm{ha}^{-1}$ belum ada yang menghasilkan respons terbaik tanaman radish. Aplikasi tanpa mulsa memiliki respons/hasil yang lebih baik dibandingkan dengan menggunakan mulsa untuk tanaman radish. Pada dosis $\mathrm{KNO}_{3}$ yang sama, tanpa menggunakan mulsa didapatkan produksi tanaman per petak yang lebih tinggi dari pada menggunakan mulsa.
\end{abstract}

Kata kunci: long white lcicle, mulsa, pupuk $\mathrm{KNO}_{3}$, radish, respons

\section{PENDAHULUAN}

Indonesia yang merupakan negara tropis memiliki keanekaragaman tumbuh-tumbuhan, diantaranya tanaman buah, tanaman hias dan tanaman sayursayuran. Keadaan iklim yang tropis menjadikan beberapa macam tanaman bisa tumbuh dan hidup subur.

Radish (Raphanus sativus L) sangat kaya akan kandungan nutrisi, mineral kalsium, fosfor, dan juga kaya serat dan fitronutrien yang baik untuk kesehatan. Selain kaya akan nutrisi, radish juga bisa diolah menjadi beragam hidangan. Tanaman radish merupakan salah satu tanaman yang tergolong dalam keluarga lobak. Menurut Rukmana (1995), radish mudah untuk dibudidayakan karena memiliki adaptasi yang sangat baik sehingga dapat ditanam di dataran tinggi ataupun dataran rendah. Struktur tanah yang baik untuk tanaman radish yaitu remah, gembur serta memiliki ketersediaan hara yang cukup tinggi.

Secara umum peranan kalium didalam $\mathrm{KNO}_{3}$ berhubungan dengan proses metabolisme, yaitu proses fotosintesis dan respirasi. Kalium juga berperan dalam proses membuka dan menutup stomata (Novizan, 2003). Kalium nitrat $\left(\mathrm{KNO}_{3}\right)$ berperan sebagai perangsang aktivitas enzim nitrat reduktase (Bondad dan Lingsangan, 1979). Kalium Nitrat $\left(\mathrm{KNO}_{3}\right)$ mengandung unsur $\mathrm{K}$ yang dapat mengaktifkan enzim penting dalam pembentukan karbohidrat dan meningkatkan tekanan tugor. Menurut Advisory Committee On Vegetable Crops (2009) kebutuhan nitrogen pada tanaman radish yaitu $60 \mathrm{~kg} \mathrm{ha}^{-1}$. Sedangkan kebutuhan Kalium pada tanaman radish menurut Cortez et al. (2010) yaitu $120 \mathrm{~kg} \mathrm{ha}^{-1}$. Kebutuhan tanaman radish akan unsur lain tidak terlalu banyak seperti unsur $\mathrm{N}$ dan $\mathrm{K}$.

Mulsa adalah bahan yang dipakai pada permukaan tanah dan berfungsi untuk menghindari kehilangan air melalui penguapan dan menekan pertumbuhan gulma (Mariano, 2003). Penggunaan mulsa dapat menekan evaporasi sehingga dapat memperbaiki pengambilan zat hara yang diberikan lewat pupuk $\mathrm{KNO}_{3}$ yang digunakan. Aplikasi pupuk $\mathrm{KNO}_{3}$ terhadap lahan yang diberi mulsa dapat meningkatkan bobot umbi radish (Guvenc, 2002).

Penelitian ini bertujuan untuk mengetahui (1) pengaruh pemberian beberapa taraf dosis pupuk $\mathrm{KNO}_{3}$ yang menghasilkan respons terbaik tanaman radish, (2) mengetahui respons tanaman radish akibat aplikasi mulsa, (3) mengetahui respons tanaman radish akibat 
pemupukan $\mathrm{KNO}_{3}$ berbagai dosis yang diaplikasikan pada lahan dengan mulsa dan tanpa mulsa.

\section{BAHAN DAN METODE}

Penelitian ini dilaksanakan di Laboraturium Lapang Terpadu Fakultas Pertanian Universitas Lampung, Kota Bandar Lampung dari bulan Mei hingga Juni 2012.

Bahan-bahan yang digunakan adalah benih radish (Raphanus sativus L.) varietas 'Long White Lcicle', mulsa plastik hitam perak, pupuk $\mathrm{KNO}_{3}$ Alat-alat yang digunakan untuk kegiatan penelitian ini adalah cangkul, koret, gembor, ember, meteran, mistar, cutter, timbangan, dan alat tulis.

Rancangan perlakuan disusun secara faktorial (5 x 2). Faktor pertama adalah dosis pupuk $\mathrm{KNO}_{3}(\mathrm{~K})$ yang terdiri dari 5 taraf, yaitu $0 \mathrm{~kg} \mathrm{ha}^{-1}\left(\mathrm{~K}_{0}\right) ; 75 \mathrm{~kg} \mathrm{ha}^{-1}$ $\left(\mathrm{K}_{1}\right) ; 150 \mathrm{~kg} \mathrm{ha}^{-1}\left(\mathrm{~K}_{2}\right) ; 225 \mathrm{~kg} \mathrm{ha}^{-1}\left(\mathrm{~K}_{3}\right)$; dan $300 \mathrm{~kg} \mathrm{ha}^{-}$ ${ }^{1}\left(\mathrm{~K}_{4}\right)$. Faktor kedua adalah aplikasi mulsa $(\mathrm{M})$ yang terdiri dari dua taraf yaitu tanpa pemberian mulsa $\left(\mathbf{M}_{0}\right)$, dan mulsa plastik hitam perak $\left(\mathrm{M}_{1}\right)$. Rancangan lingkungan yang digunakan adalah rancangan kelompok teracak sempurna (RKTS) dengan tiga ulangan. Keragaman data diuji dengan uji Bartlett dan sifat kemenambahan data diuji dengan uji Tukey. Data diolah dengan analisis ragam, dilanjutkan dengan uji Polinomial Orthogonal dan ortogonal Kontras. Semua pengujian dilakukan pada taraf nyata $5 \%$ dan $1 \%$.

Lahan digemburkan dan dibuat bedengan sebanyak 30 yang dibagi menjadi tiga ulangan. Kemudian lahan diberi pupuk kandang kambing dengan takaran 2 $\mathrm{kg} /$ petak dan diberakan selama 4 hari. Pupuk dasar Urea dan SP36 diberikan secara bersamaan dengan cara ditabur dengan dosis masing-masing $20 \mathrm{~g}$ per petak, 30 g per petak. Pemasangan mulsa dilakukan setelah aplikasi pupuk. Jarak tanam yang digunakan adalah 10 $\mathrm{cm}$ x $20 \mathrm{~cm}$, dan ditanami benih radish sebanyak 24 benih per petak. Pemeliharaan tanaman meliputi pengairan atau penyiraman, pembumbunan, penyiangan tumbuhan pengganggu, dan pemberantasan hama penyakit. Panen dilakukan 50 hari setelah tanam.

Untuk menguji kesahihan kerangka pemikiran dan hipotesis dilakukan pengamatan terhadap komponen pertumbuhan dan produksi. Setiap petak percobaan diambil tujuh sampel tanaman. Dengan variabel pengamatan meliputi peubah sebagai berikut: (1) jumlah daun tanaman dihitung dengan satuan helai, (2) bobot basah umbi radish diukur dengan satuan g, (3) bobot kering brangkasan, (4) diameter umbi radish, (5) voleme umbi radish, (6) produksi tanaman per petak.

\section{HASIL DAN PEMBAHASAN}

Hasil penelitian menunjukkan bahwa antara perlakuan yang diberi mulsa, tanpa mulsa dan pemberian $\mathrm{KNO}_{3}$ hingga dosis $300 \mathrm{~kg} \mathrm{ha}^{-1}$ tidak berpengaruh nyata terhadap penambahan jumlah daun tanaman (Tabel 1).

Hasil penelitian menunjukkan bahwa aplikasi tanpa mulsa secara nyata menghasilkan bobot umbi sampel lebih besar 62,08 g/1,5 $\mathrm{m}^{2}(18,46 \%)$ dibandingkan dengan menggunakan mulsa (Tabel 2). Pada perlakuan mulsa maupun tanpa mulsa, respons tanaman radish terhadap dosis $\mathrm{KNO}_{3}$ sampai $300 \mathrm{~kg} \mathrm{ha}^{-1}$ masih linier dalam peubah bobot umbi tanaman radish (Gambar 1).

Hasil penelitian menunjukkan bahwa perlakuan tanpa mulsa secara nyata menghasilkan bobot kering brangkasan tanaman radish lebih besar $6,40 \mathrm{~g} / 1,5 \mathrm{~m}^{2}$ $(18,27 \%)$ dibanding dengan mulsa (Tabel 3). Pada perlakuan mulsa dan tanpa mulsa, pemberian pupuk

Tabel 1. Tanggapan jumlah daun terhadap penggunaan mulsa dan pemberian $\mathrm{KNO}_{3}$

\begin{tabular}{|c|c|c|c|}
\hline \multirow{2}{*}{ Perlakuan } & \multicolumn{2}{|c|}{ Selisih } & \multirow{2}{*}{ Signifikans } \\
\hline & Jumlah daun & $\%$ & \\
\hline Mulsa (M) & & & \\
\hline C1: $\mathrm{M}_{0}$ vs $\mathrm{M}_{1}$ & $-2,04$ & $-4,53$ & tn \\
\hline C2: K-Linier & & & tn \\
\hline C3: K-Kuadratik & & & tn \\
\hline Interaksi (M x K) & & & \\
\hline $\mathrm{C} 4: \mathrm{C} 1$ x $\mathrm{C} 2$ & & & tn \\
\hline $\mathrm{C} 5: \mathrm{C} 1 \times \mathrm{C} 3$ & & & tn \\
\hline
\end{tabular}

Keterangan: $\mathrm{M}_{0}=$ tanpa mulsa, $\mathrm{M}_{1}=$ dengan mulsa, $\mathrm{tn}=$ tidak nyata pada $\alpha=0,05$ 
Tabel 2. Tanggapan bobot umbi tanaman radish terhadap penggunaan mulsa dan pemberian $\mathrm{KNO}_{3}$

\begin{tabular}{|c|c|c|c|}
\hline \multirow{2}{*}{ Perlakuan } & \multicolumn{2}{|c|}{ Selisih } & \multirow{2}{*}{ Signifikansi } \\
\hline & Bobot umbi sampel (g) & $\%$ & \\
\hline \multicolumn{4}{|l|}{ Mulsa (M) } \\
\hline $\begin{array}{l}\mathrm{C} 1: \mathrm{M}_{0} \text { vs } \mathrm{M}_{1} \\
\mathrm{KNO} 3(\mathrm{~K})\end{array}$ & 62,08 & 18,46 & $*$ \\
\hline C2: K-Linier & & & $* *$ \\
\hline C3: K-Kuadratik & & & $* *$ \\
\hline \multicolumn{4}{|l|}{ Interaksi (M x K) } \\
\hline $\mathrm{C} 4: \mathrm{C} 1 \times \mathrm{C} 2$ & & & tn \\
\hline $\mathrm{C} 5: \mathrm{C} 1 \times \mathrm{C} 3$ & & & tn \\
\hline
\end{tabular}

Keterangan: $\mathrm{M}_{0}=$ tanpa mulsa, $\mathrm{M}_{1}=$ dengan mulsa, $\mathrm{tn}=$ tidak nyata pada $\alpha=0,05,{ }^{*}=$ nyata pada $\alpha=0,05$.

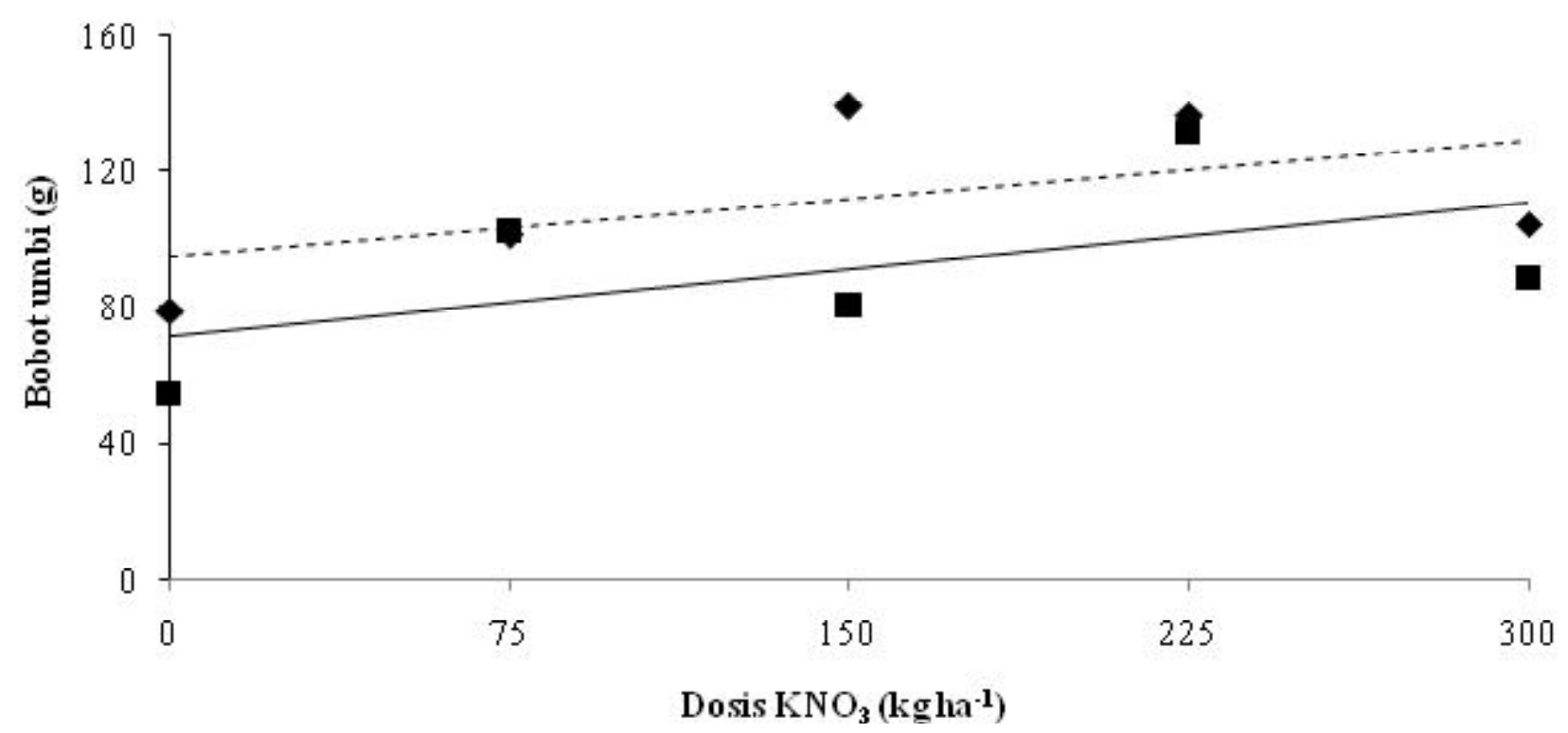

Gambar 1. Hubungan antara dosis $\mathrm{KNO}_{3}$ dengan bobot umbi radish pada perlakuan pemberian mulsa dan tanpa mulsa. Garis putus-putus $=\mathrm{M}_{0}$ (tanpa mulsa), $\mathrm{ym}_{0}=0,1143 \mathrm{x}+94,9239$ dan garis utuh $=\mathrm{M}_{1}$ (dengan mulsa), $\mathrm{ym}_{1}=0,1294 \mathrm{x}+71,9653$.

Tabel 3. Tanggapan bobot kering brangkasan tanaman radish terhadap penggunaan mulsa dan pemberian $\mathrm{KNO}_{3}$

\begin{tabular}{|c|c|c|c|}
\hline \multirow{2}{*}{ Perlakuan } & \multicolumn{2}{|l|}{ Selisih } & \multirow{2}{*}{ Signifikansi } \\
\hline & Bobot kering brangkasan (g) & $\%$ & \\
\hline \multicolumn{4}{|l|}{ Mulsa (M) } \\
\hline $\mathrm{C} 1: \mathrm{M}_{0}$ vs $\mathrm{M}_{1}$ & 6,40 & 18,27 & $* *$ \\
\hline \multicolumn{4}{|l|}{$\mathrm{KNO} 3(\mathrm{~K})$} \\
\hline C2: K-Linier & & & $* *$ \\
\hline C3: K-Kuadratik & & & $* *$ \\
\hline \multicolumn{4}{|l|}{ Interaksi (M x K) } \\
\hline $\mathrm{C} 4: \mathrm{C} 1 \times \mathrm{C} 2$ & & & tn \\
\hline $\mathrm{C} 5: \mathrm{C} 1$ x C3 & & & $\operatorname{tn}$ \\
\hline
\end{tabular}

Keterangan: $\mathrm{M}_{0}=$ tanpa mulsa, $\mathrm{M}_{1}=$ dengan mulsa, $\mathrm{tn}=$ tidak nyata pada $\alpha=0,05, * *=$ sangat nyata pada $\alpha=$ 0,01 . 
$\mathrm{KNO}_{3}$ meningkatkan bobot kering brangkasan sampai dosis $\mathrm{KNO}_{3} 300 \mathrm{~kg} \mathrm{ha}^{-1}$ yang dicobakan masih menghasilkan kurva yang linier (Gambar 2).

Hasil penelitian menunjukkan bahwa tanpa pemberian mulsa secara nyata menghasilkan diameter umbi tanaman radish lebih besar $0,75 \mathrm{~cm}(8,17 \%)$ dibandingkan dengan pemakaian mulsa dan tidak ada interaksi antara kedua perlakuan pemberian mulsa dengan pemberian $\mathrm{KNO}_{3}$ (Tabel 4). Pada perlakuan mulsa dan tanpa mulsa, pemberian pupuk $\mathrm{KNO}_{3}$ meningkatkan diameter umbi sampai dosis $300 \mathrm{~kg} \mathrm{ha}^{-1}$ masih menghasilkan kurva yang linier (Gambar 3).
Hasil penelitian menunjukkan bahwa tanpa mulsa sangat nyata menghasilkan volume umbi radish lebih besar $0,46 \mathrm{~mm}^{2}(5,17 \%)$ dibandingkan perlakuan dengan menggunakan mulsa (Tabel 5). Pada perlakuan mulsa dan tanpa mulsa, pemberian pupuk $\mathrm{KNO}_{3}$ meningkatkan diameter umbi hingga dosis $\mathrm{KNO}_{3} 300 \mathrm{~kg} \mathrm{ha}^{-1}$ masih menghasilkan kurva yang linier (Gambar 4).

Hasil penelitian menunjukkan bahwa perlakuan tanpa mulsa sangat nyata menghasilkan produksi tanaman per petak tanaman radish lebih besar 826,89 $\mathrm{g} / 1,5 \mathrm{~m}^{2}(27,18 \%)$ dibanding dengan mulsa (Tabel 6). Pada perlakuan mulsa dan tanpa mulsa, pemberian

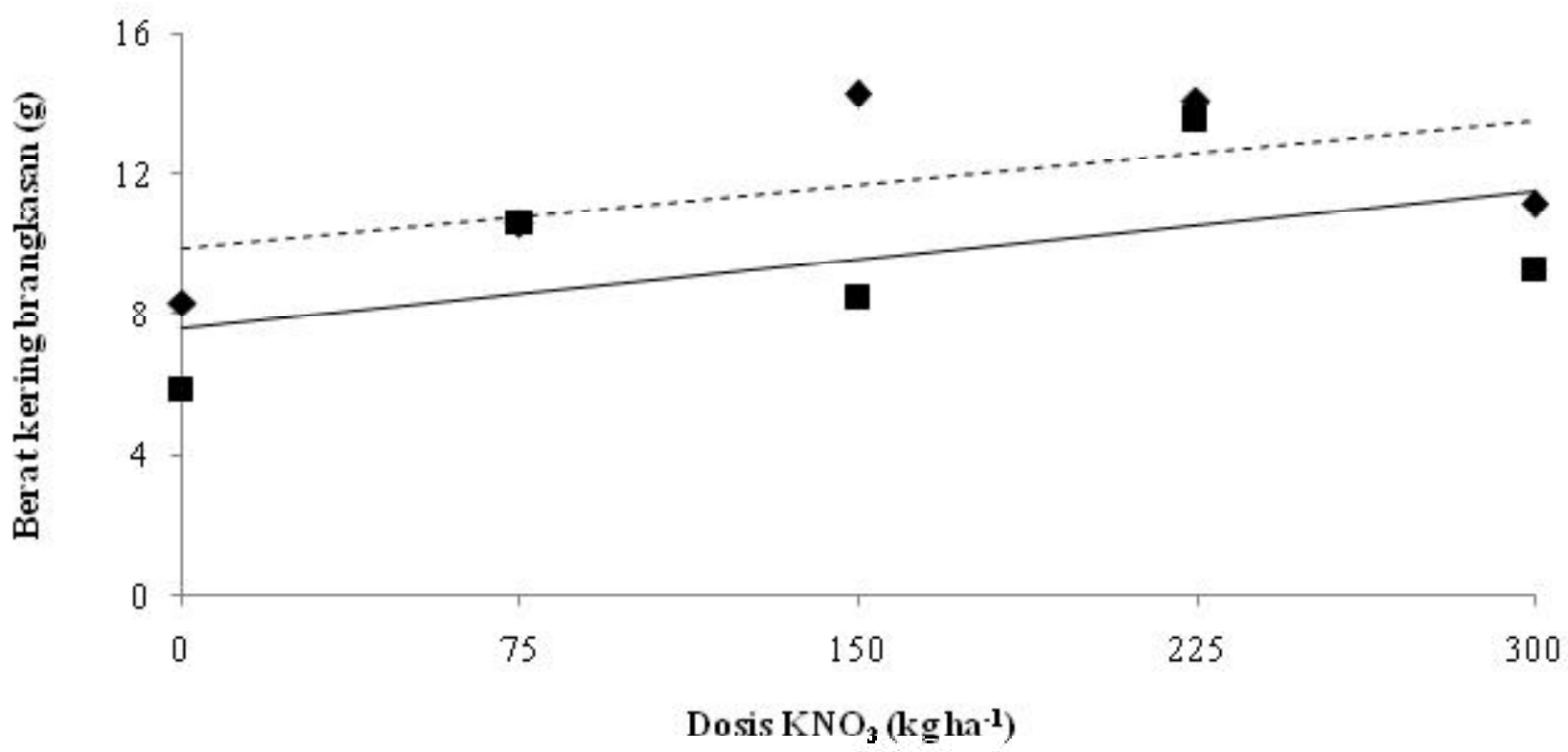

Gambar 2. Hubungan antara dosis $\mathrm{KNO}_{3}$ dengan bobot kering brangkasan tanaman radish pada perlakuan pemberian mulsa dan tanpa mulsa. Garis putus-putus $=\mathrm{M}_{0}$ (tanpa mulsa), $\mathrm{ym}_{0}=0,01223 \mathrm{x}+9,83559$ dan garis utuh $=\mathrm{M}_{1}$ (dengan mulsa), $\mathrm{ym}_{1}=0,01294 \mathrm{x}+7,59653$.

Tabel 4. Tanggapan diameter umbi radish terhadap penggunaan mulsa dan pemberian $\mathrm{KNO}_{3}$

\begin{tabular}{|c|c|c|c|}
\hline \multirow{2}{*}{ Perlakuan } & \multicolumn{2}{|c|}{ Selisih } & \multirow{2}{*}{ Signifikansi } \\
\hline & Diameter umbi $(\mathrm{cm})$ & $\%$ & \\
\hline Mulsa (M) & & & \\
\hline $\begin{array}{l}\mathrm{C} 1: \mathrm{M}_{0} \text { vs } \mathrm{M}_{1} \\
\mathrm{KNO} 3(\mathrm{~K})\end{array}$ & 0,75 & 8,17 & ** \\
\hline C2: K-Linier & & & $* *$ \\
\hline C3: K-Kuadratik & & & $* *$ \\
\hline Interaksi (M x K) & & & \\
\hline $\mathrm{C} 4: \mathrm{C} 1 \times \mathrm{C} 2$ & & & tn \\
\hline $\mathrm{C} 5: \mathrm{C} 1 \times \mathrm{C} 3$ & & & tn \\
\hline
\end{tabular}

Keterangan: $\mathrm{M}_{0}=$ tanpa mulsa, $\mathrm{M}_{1}=$ dengan mulsa, $\mathrm{tn}=$ tidak nyata pada $\alpha=0,05, * *$ sangat nyata pada $\alpha=$ 0,01 . 


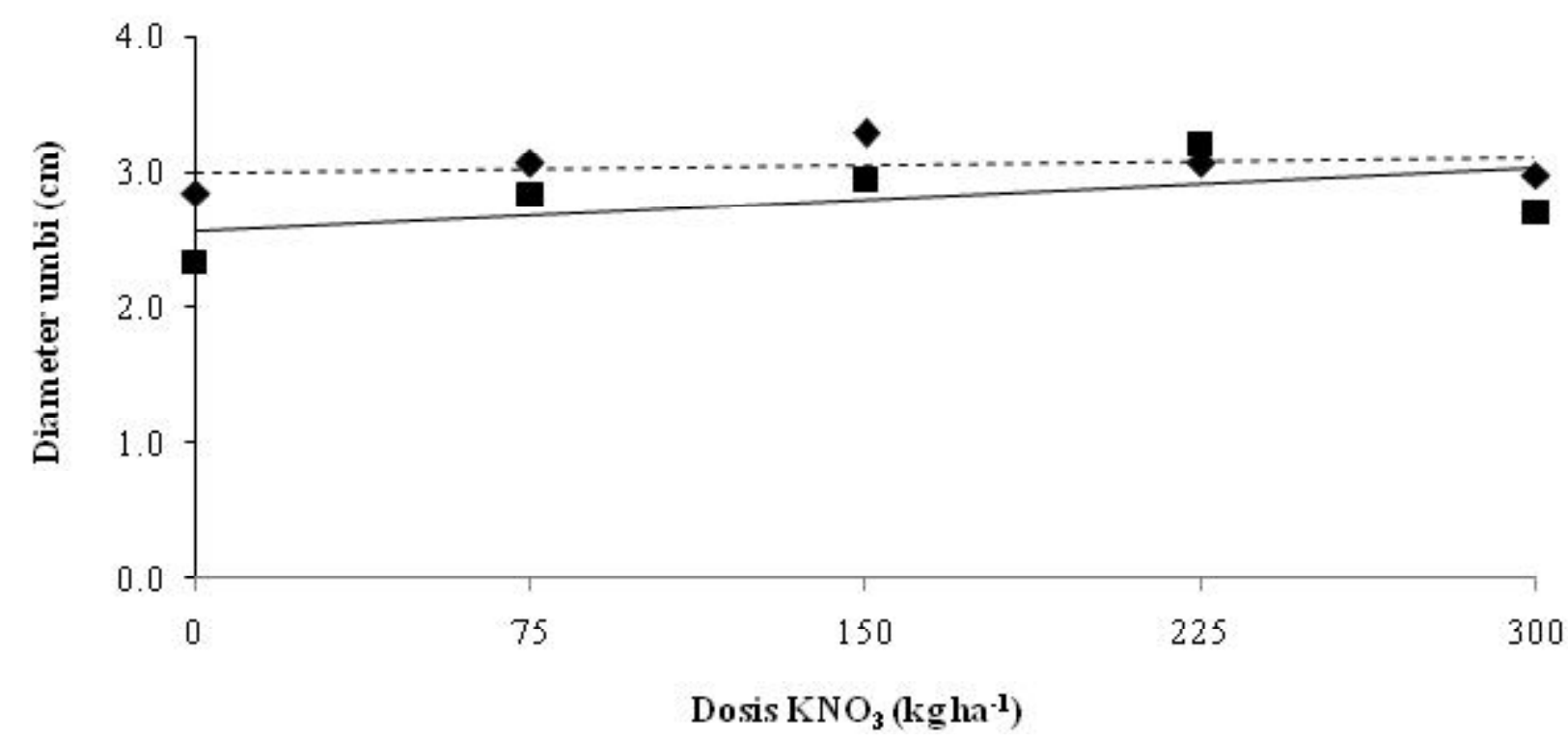

Gambar 3. Hubungan antara dosis $\mathrm{KNO}_{3}$ dengan diameter umbi radish pada perlakuan pemberian mulsa dan tanpa mulsa. Garis putus-putus $=\mathrm{M}_{0}$ (tanpa mulsa), $\mathrm{ym}_{0}=0,001502 \mathrm{x}+2,576$ dan garis utuh $=\mathrm{M}_{1}$ (dengan mulsa), $\mathrm{ym}_{1}=0,000347 \mathrm{x}+2,998667$.

Tabel 5. Tanggapan volume umbi tanaman radish terhadap penggunaan mulsa dan pemberian $\mathrm{KNO}_{3}$

\begin{tabular}{|c|c|c|c|}
\hline \multirow[b]{2}{*}{ Perlakuan } & \multicolumn{2}{|c|}{ Selisih } & \multirow[b]{2}{*}{ Signifikansi } \\
\hline & Volume umbi $\left(\mathrm{mm}^{3}\right)$ & $\%$ & \\
\hline \multicolumn{4}{|l|}{ Mulsa (M) } \\
\hline C1: $\mathrm{M}_{0}$ vs $\mathrm{M}_{1}$ & 0,46 & 5,17 & $*$ \\
\hline \multicolumn{4}{|l|}{$\mathrm{KNO} 3(\mathrm{~K})$} \\
\hline C2: K-Linier & & & $* *$ \\
\hline C3: K-Kuadratik & & & $* *$ \\
\hline \multicolumn{4}{|l|}{ Interaksi (M x K) } \\
\hline $\mathrm{C} 4: \mathrm{C} 1 \times \mathrm{C} 2$ & & & tn \\
\hline $\mathrm{C} 5: \mathrm{C} 1 \times \mathrm{C} 3$ & & & $\operatorname{tn}$ \\
\hline
\end{tabular}

Keterangan: $\mathrm{M}_{0}=$ tanpa mulsa, $\mathrm{M}_{1}=$ dengan mulsa, $\mathrm{tn}=$ tidak nyata pada $\alpha=0,05, *$ nyata pada $\alpha=0,05, * *$ = sangat nyata pada $\alpha=0,01$.

pupuk $\mathrm{KNO}_{3}$ meningkatkan produksi tanaman per petak hingga dosis $\mathrm{KNO}_{3} 300 \mathrm{~kg} \mathrm{ha}^{-1}$ masih menghasilkan kurva yang linier (Gambar 5).

Hasil penelitian menunjukkan bahwa pemberian pupuk $\mathrm{KNO}_{3}$ miningkatkan bobot umbi, produksi per petak, diameter umbi, volume umbi dan bobot kering berangkasan. Hal ini sesuai dengan fungsi dari $\mathrm{KNO}_{3}$ pada tanaman radish itu sendiri yaitu membantu proses pembentukan umbi. Secara umum peranan kalium didalam $\mathrm{KNO}_{3}$ berhubungan dengan proses metabolisme, yaitu proses fotosintesis dan respirasi. Kalium berperan sebagai katalis dalam berbagai reaksi enzimatis serta dalam perkembangan jaringan tanaman.
Kalium juga berfungsi untuk mempercepat metabolisme unsur nitrogen serta berperan dalam mengedarkan karbohidrat di dalam tanaman, sehingga mendapatkan hasil yang produksi lebih baik (Guvenc, 2002).

Penggunaan mulsa dapat menekan evaporasi sehingga dapat memperbaiki pengambilan zat hara yang diberikan lewat pupuk $\mathrm{KNO}_{3}$ yang digunakan. Aplikasi pupuk $\mathrm{KNO}_{3}$ terhadap lahan yang diberi mulsa dapat meningkatkan bobot umbi radish (Guvenc, 2002). Akan tetapi hal yang terjadi tidak demikian, pada pelaksanaan penelitian yang telah dilakukan didapat bahwa perlakuan mulsa lebih rendah dari perlakuan tanpa mulsa. Hal ini karena penggunaan mulsa disuhu yang cukup tinggi yaitu 


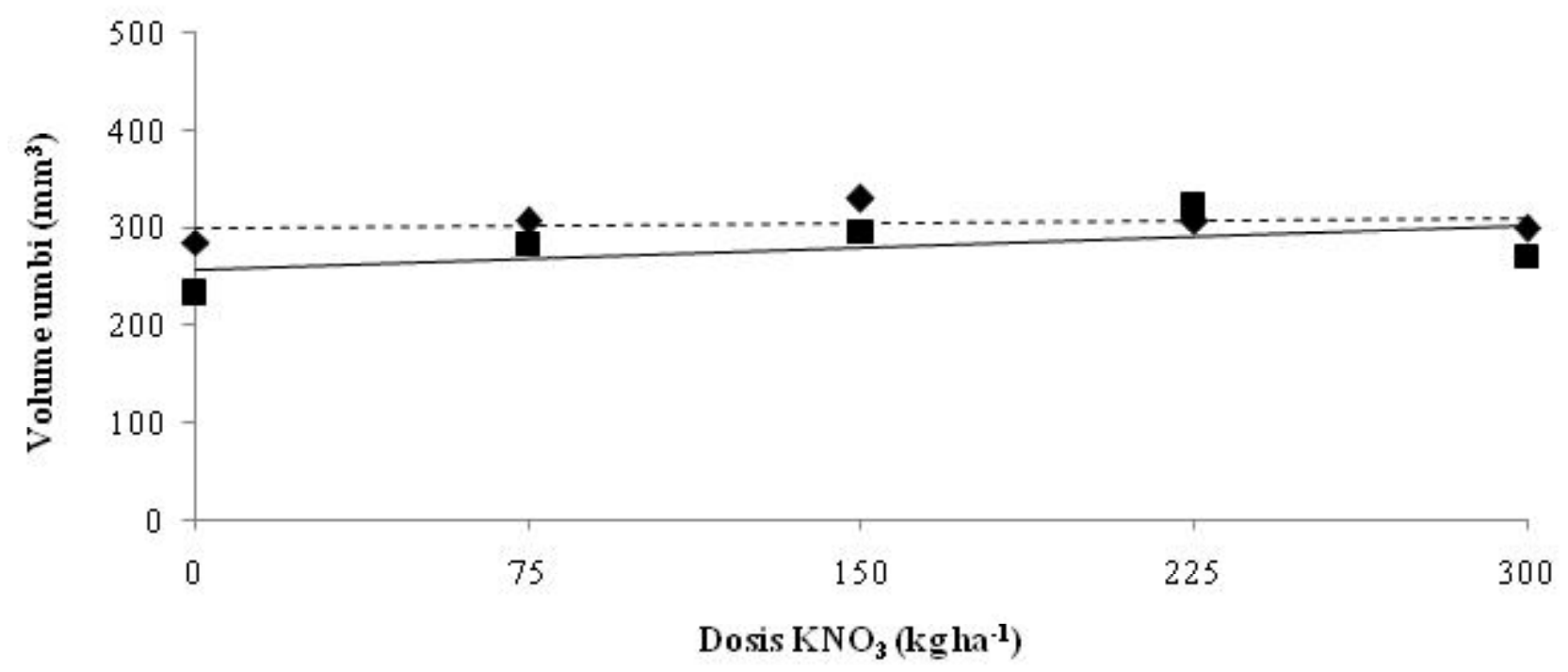

Gambar 4. Hubungan antara dosis $\mathrm{KNO}_{3}$ dengan volume umbi radish pada perlakuan pemberian mulsa dan tanpa mulsa. Garis putus-putus $=\mathrm{M}_{0}$ (tanpa mulsa), $\mathrm{ym}_{0}=0,034 \mathrm{x}+299,8$ dan garis utuh $=\mathrm{M}_{1}$ (dengan mulsa), $\mathrm{ym}_{1}=0,150 \mathrm{x}+257,6$.

Tabel 6. Tanggapan produksi tanaman per petak tanaman radish terhadap penggunaan mulsa dan pemberian KNO

\begin{tabular}{|c|c|c|c|}
\hline \multirow{2}{*}{ Perlakuan } & \multicolumn{2}{|c|}{ Selisih } & \multirow{2}{*}{ Signifikansi } \\
\hline & Produksi perpetak (g) & $\%$ & \\
\hline \multicolumn{4}{|l|}{ Mulsa (M) } \\
\hline $\mathrm{C} 1: \mathrm{M}_{0}$ vs $\mathrm{M}_{1}$ & 826,89 & 27,18 & $* *$ \\
\hline \multicolumn{4}{|l|}{$\mathrm{KNO} 3(\mathrm{~K})$} \\
\hline C2: K-Linier & & & $* *$ \\
\hline C3: K-Kuadratik & & & $* *$ \\
\hline \multicolumn{4}{|l|}{ Interaksi (M x K) } \\
\hline $\mathrm{C} 4: \mathrm{C} 1 \times \mathrm{C} 2$ & & & $* *$ \\
\hline $\mathrm{C} 5: \mathrm{C} 1 \times \mathrm{C} 3$ & & & $* *$ \\
\hline \multicolumn{4}{|c|}{ Tanggapan Terhadap M Pada } \\
\hline $\mathrm{K}_{0}: \mathrm{M}_{0}$ vs $\mathrm{M}_{1}$ & 215,83 & 50,37 & $* *$ \\
\hline $\mathrm{K}_{1}: \mathrm{M}_{0} \mathrm{vs}_{1}$ & 200,33 & 35,37 & $* *$ \\
\hline $\mathrm{K}_{2}: \mathrm{M}_{0}$ vs $\mathrm{M}_{1}$ & 298,38 & 38,85 & $* *$ \\
\hline $\mathrm{K}_{3}: \mathrm{M}_{0} \mathrm{vs}_{1}$ & 121,31 & 16,17 & $* *$ \\
\hline $\mathrm{K}_{4}: \mathrm{M}_{0}$ vs $\mathrm{M}_{1}$ & $-8,94$ & $-1,69$ & $* *$ \\
\hline \multicolumn{4}{|c|}{ Tanggapan Terhadap K Pada } \\
\hline $\mathrm{M}_{0}: \mathrm{K}$-Linier & & & $* *$ \\
\hline $\mathrm{M}_{0}:$ K-Kuadratik & & & $* *$ \\
\hline $\mathrm{M}_{1}:$ K-Linier & & & $* *$ \\
\hline $\mathrm{M}_{1}:$ K-Kuadratik & & & $* *$ \\
\hline
\end{tabular}

Keterangan: $\mathrm{M}_{0}=$ tanpa mulsa, $\mathrm{M}_{1}=$ dengan mulsa, $\mathrm{tn}=$ tidak nyata pada $\alpha=0,05$, ** = nyata pada $\alpha=0,01, \mathrm{~K}_{0}$ $-\mathrm{K}_{4}=$ dosis $\mathrm{KNO}_{3}$ berturut-turut $0 \mathrm{~kg} \mathrm{ha}^{-1}, 75 \mathrm{~kg} \mathrm{ha}^{-1}, 150 \mathrm{~kg} \mathrm{ha}^{-1}, 225 \mathrm{~kg} \mathrm{ha}^{-1}, 300 \mathrm{~kg} \mathrm{ha}^{-1}$. 
dengan suhu antara $23,4^{\circ}-32,4^{\circ} \mathrm{C}$ (Tabel 7 , suhu ratarata kota Bandar Lampung bulan Mei - Juni pada tahun 2008 - 2011) akan menghambat pertumbuhan tanaman radish.

Dosis pupuk $\mathrm{KNO}_{3}$ sampai dosis $300 \mathrm{~kg} \mathrm{ha}^{-1}$ belum ada yang menghasilkan respons terbaik tanaman radish. Pada peubah bobot umbi, produksi per petak, diameter umbi, volume umbi, dan bobot kering brangkasan semakin meningkat sampai dosis $\mathrm{KNO}_{3}$ terbesar yang dicobakan. Kombinasi perlakuan $\mathrm{KNO}_{3}$ dan tanpa mulsa menghasilkan produksi perpetak lebih baik dengan titik maksimum pada dosis $150 \mathrm{~kg} \mathrm{ha}^{-1}$ sebesar 1271,82 g/1,5 $\mathrm{m}^{2}$ dibandingkan dengan kombinasi perlakuan lainnya pada tanaman radish. Aplikasi tanpa mulsa memiliki respons/hasil yang lebih baik dibandingkan dengan menggunakan mulsa untuk tanaman radish, pada peubah bobot umbi sampel yaitu $18,45 \%$; bobot kering brangkasan yaitu $18,27 \%$; diameter umbi yaitu $8,17 \%$; volume umbi yaitu $5,17 \%$; produksi tanaman per petak yaitu $27,18 \%$. Pada dosis $\mathrm{KNO}_{3}$ yang sama, tanpa menggunakan mulsa didapatkan produksi tanaman per petak yang lebih tinggi dari pada menggunakan mulsa.

\section{KESIMPULAN}

Berdasarkan hasil penelitian dapat disimpulkan bahwa respons tanaman radish terhadap dosis $\mathrm{KNO}_{3}$ sampai dosis $300 \mathrm{~kg} \mathrm{ha}^{-1}$ masih linier. Perlakuan tanpa mulsa pada tanaman radish menujukkan hasil yang lebih baik

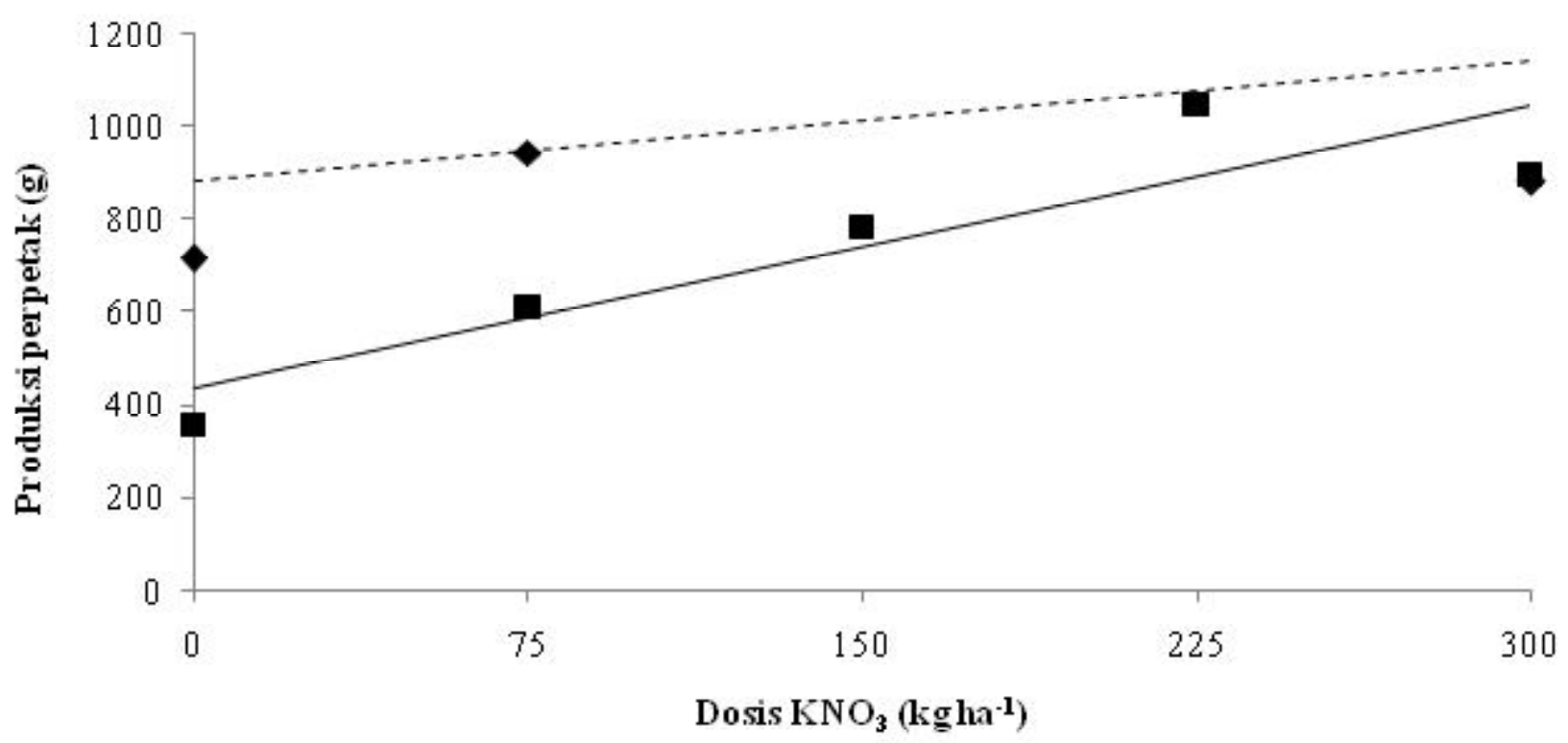

Gambar 5. Hubungan antara dosis $\mathrm{KNO}_{3}$ dengan produksi per petak tanaman radish pada perlakuan pemberian mulsa dan tanpa mulsa. Garis putus-putus $=\mathrm{M}_{0}$ (tanpa mulsa), $\mathrm{ym}_{0}=0,855 \mathrm{x}+885,6$ dan garis utuh $=$ $\mathrm{M}_{1}$ (dengan mulsa), $\mathrm{ym}_{1}=2,030 \mathrm{x}+433,8$.

Tabel 7. Rata-rata suhu minimum dan maksimum kota Bandar Lampung bulan Mei-Juni tahun 2008-201

\begin{tabular}{lcccc}
\hline \multicolumn{2}{l}{ Rata-rata suhu udara minimum $\left({ }^{0} \mathrm{C}\right)$} & & & \\
\hline Bulan/tahun & 2008 & 2009 & 2010 & 2011 \\
\hline Mei & 22,6 & 23,5 & 24,8 & 23,6 \\
Juni & 22,7 & 23,3 & 23,7 & 22,4 \\
\hline \multicolumn{2}{l}{ Rata-rata suhu udara maksimum $\left({ }^{0} \mathrm{C}\right)$} & & & \\
\hline Mei & 33 & 32,6 & 32,8 & 32,6 \\
Juni & 31,8 & 32,4 & 31,7 & 32,4 \\
\hline
\end{tabular}


dibandingkan dengan menggunakan mulsa pada peubah bobot umbi sampel, bobot kering brangkasan, diameter umbi, volume umbi, produksi tanaman per petak. Pada pemberian $\mathrm{KNO}_{3}$ dosis $0-225 \mathrm{~kg} \mathrm{ha}^{-1}$ perlakuan tanpa mulsa peubah produksi tanaman per petak lebih tinggi dibandingkan dengan mulsa, tetapi pada dosis yang lebih tinggi (300 $\mathrm{kg} \mathrm{ha}^{-1}$ ) perlakuan tanpa mulsa tidak menunjukkan perbedaan hasil.

\section{DAFTAR PUSTAKA}

Advisory Committee on Vegetable Crops. 2009. Radish. Atlantic Provinces Agriculture Services Coordinating Committee. Atlantic Provinces.

Bondad, L.H. and Lingsangan. 1979. Flowering in Mango Induced With Potassium Nitrate. Hort. Sci. 14:527-528.
Cortez J.W.M, Arthur B. Cecílio Filho, Edson L. Coutinho, and Anarlete Alves. 2010. Cattle manure and $\mathrm{N}$-urea in radish crop (Raphanus sativus). Cien. Inv. Agr. 37(1):45-53.

Guvenc, I. 2002. Effect of nitrogen fertilization on growth, yield and nitrogen contents of radishes. Gartenbauwissenschaft 67(1)S: 23-27.

Mariano, A.S.A. 2003. Pengaruh Pupuk Foska dan Mulsa Jerami terhadap Beberapa Sifat Fisik dan Kimia Tanah serta Produksi Kedelai (Glycine $\max$ L. Merr). (Tesis). Institut Pertanian Bogor.

Novizan. 2005. Petunjuk Pemupukan yang Efektif. Gedia Pustaka. Jakarta.

Rukmana, R. 1995. Bertanam Lobak. Kanisius. Malang. 